\title{
Pyruvate Carboxylase Deficiency and Lactic Acidosis in a Retarded Child without Leigh's Disease
}

\author{
BETH M. ATKIN, NEIL R. M. BUIST, MERTON F. UTTER, ANDREW B. LEITER, \\ AND BETTY Q. BANKER \\ Division of Medical Genetics and the Department of Pediatrics, University of Oregon Health Sciences Center, \\ Portland, Oregon and Departments of Biochemistry and Pathology (Neuropathology), School of Medicine, Case \\ Western Reserve University, Cleveland, Ohio, 44106 USA
}

\section{Summary}

A child with lactic acidosis, severe mental and developmental retardation, and proximal renal tubular acidosis is presented. Biopsy and autopsy studies show severe hepatic, renal cortical, and cerebral deficiencies in pyruvate carboxylase (EC 6.4.1.1) activity. The patient had $1.81 \pm 0.20$ units/g fresh weight at biopsy and $0.75 \pm 0.07$ units $/ g$ fresh weight hepatic pyruvate carboxylase activity at autopsy compared with 10.9, 11.3, and 9.5 units/g fresh weight in two autopsy and one biopsy controls, respectively. The patient's renal cortical pyruvate carboxylase activity at autopsy was $0.008 \pm 0.004$ units/g fresh weight compared with 5.05 units/ $\mathrm{g}$ in the autopsy control. The patient had no detectable $(<0.018$ units/g fresh weight) cerebral pyruvate carboxylase activity at autopsy compared with $0.44,0.53$, and 0.695 units/g in the autopsy cerebrum of one human and two rhesus monkeys, respectively. Pyruvate dehydrogenase complex, phosphoenolpyruvate carboxykinase (PEPCK, EC 4.1.1.32), and fructose-1,6-bisphosphatase (EC 3.1.3.11) activities were in the normal range. The patient's urine $\mathrm{pH}$ was above 7.9 when the total serum $\mathrm{CO}_{2}$ was greater than $7.8 \mathrm{mM}$. However, the patient was able to acidify the urine to $\mathrm{pH} 5.1$ when the total serum $\mathrm{CO}_{2}$ was $1.6 \mathrm{mM}$. The neuropathologic examination of the brain at autopsy revealed no sign of Leigh's disease, although developmental and degenerative lesions were observed. This is the first reported patient with a primary deficiency in hepatic, renal, and cerebral pyruvate carboxylase deficiency in whom the neuropathologic lesions, distinct from those of Leigh's disease, and proximal renal tubular acidosis have both been documented.

\section{Speculation}

Application to future patients of methods for the optimal storage and assay of tissues for pyruvate carboxylase activity plus a thorough examination of autopsy brain will demonstrate that the neuropathologic lesions accompanying pyruvate carboxylase deficiency are distinct from those of Leigh's disease.

Congenital lactic acidosis, as distinguished from lactic acidosis due to tissue hypoxia and other causes, has been associated with several enzymatic deficiencies. The following enzymes involved in glucose or pyruvate metabolism (Fig. 1) have been implicated: glucose-6-phosphatase $(24,29)$, fructose-1,6-bisphosphatase $(31$, $32)$, pyruvate carboxylase $(7,10,12,13,19,20,22,37,40,41)$, and pyruvate dehydrogenase complex $(6,15,36,39)$. Of these enzymes all but the last are required for gluconeogenesis. Deficiency in PEPCK $(16,21)$, the other enzyme essential to gluconeogenesis, has been associated with fasting hypoglycemia but not spontaneous lactic acidosis. The presentation of congenital lactic acidosis has varied from neonatal death to mild, late onset symptoms involving the central nervous system.

Pyruvate carboxylase catalyzes the first step in the synthesis of glucose from pyruvate in kidney and liver. Therefore, a defect in this enzyme would be expected to produce fasting hypoglycemia and increased tissue concentrations of pyruvate and metabolically related substances such as lactate and alanine. Pyruvate carboxylase also occurs in relatively high levels in brain and adipose tissue (5). The role of the enzyme in kidney has been assumed to be primarily in gluconeogenesis, but the existence of proximal renal tubular acidosis in the present case and that of Gruskin $e t$ al. (20) suggests that it may play a role in $\mathrm{HCO}_{3}^{-}$reabsorption. Likewise, the function of the enzyme in brain is not well understood, although it may be to furnish oxalacetate, and cytosolic acetyl groups and reducing equivalents for various cellular functions.

Several patients $(10,12,19,20,22,40,41)$ with progressive neurologic deterioration clinically resembling subacute necrotizing encephalomyelopathy (Leigh's disease) (27) have been reported to have hepatic pyruvate carboxylase deficiency. This has led some investigators to conclude that Leigh's disease may be caused by pyruvate carboxylase deficiency. Leigh's disease has been associated with an ATP-thiamine diphosphate phosphoryltransferase inhibitor in the blood, cerebrospinal fluid, and urine of patients and relatives (11), but the disease can only be diagnosed positively by finding a characteristic pattern of brain lesions at autopsy (34).

This report presents the case report and attempted therapy of a patient with lactic acidosis, proximal renal tubular acidosis, and severe mental and developmental retardation concomitant with hepatic, renal cortical, and cerebral pyruvate carboxylase deficiency. As described elsewhere (3), the patient had virtually no pyruvate carboxylase activity in lymphocytes or skin fibroblasts, in contrast to control tissues. The neurologic lesions of the patient at autopsy are described and contrasted with those found in patients with Leigh's disease. A method is given for the optimal assay of pyruvate carboxylase in human liver, brain, and kidney.

\section{MATERIALS AND METHODS}

\section{ANALYTICAL METHODS}

Amino acids were determined by single-column ion-exchange chromatography $(8)$ and volatile acids in serum $(2,33)$ and total organic acids in urine and serum (23) were determined by gas chromatography. Lactate and pyruvate $(25)$ and $\beta$-hydroxybutyrate and acetoacetate (18) were determined as described. The assay for the inhibitor of thiamine triphosphate synthesis was similar to that of Pincus et al. (35). Protein was determined according to the method of Lowry et al. (30). 


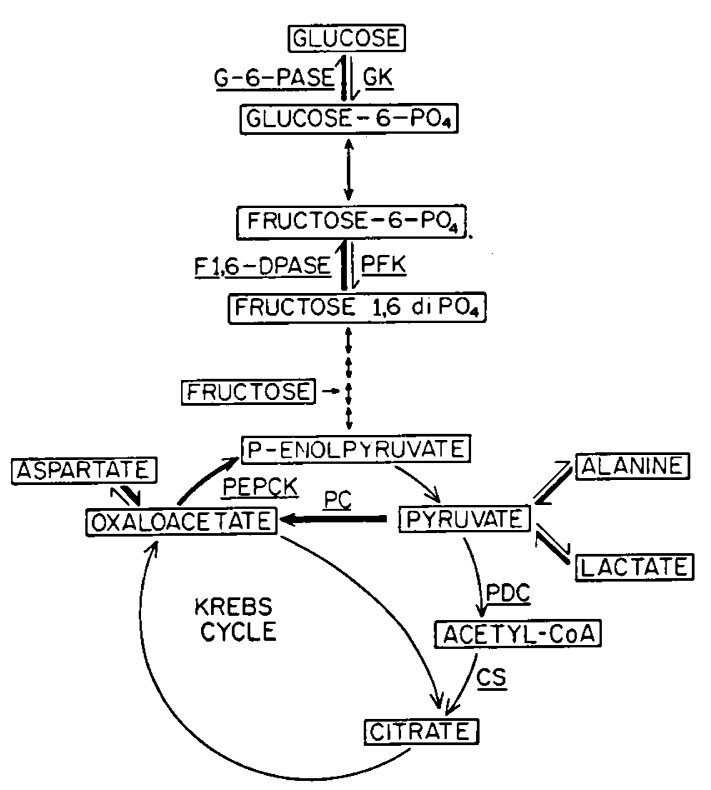

Fig. 1. Pathways of glycolysis, Krebs cycle, and gluconeogenesis in liver. Gluconeogenic pathway is represented by heavy arrows. GK, glucokinase; G-6-Pase, glucose-6-phosphatase; PFK, phosphofructokinase; F 1,6DPase, fructose-1,6-bisphosphatase; PDC, pyruvate dehydrogenase complex; PC, pyruvate carboxylase; CS, citrate synthase; and PEPCK.

\section{MEASUREMENTS OF ENZYMATIC ACTIVITIES}

Pyruvate carboxylase activity was measured by an isotopic assay based on a modification of earlier studies of Utter and Keech (42) and Ballard and Hanson (4). The assay included: $45 \mu$ mole Tris$\mathrm{HCl}, \mathrm{pH} 7.8 ; 5 \mu$ mole $\mathrm{MgCl}_{2} ; 2.0 \mu$ mole ATP; $0.33 \mu$ mole acetyl CoA; $10 \mu$ mole $\mathrm{NaH}^{14} \mathrm{CO}_{3}\left(0.1 \mathrm{mCi} / \mathrm{mmole} \mathrm{HCO}_{3}{ }^{-}\right) ; 50 \mu$ mole $\mathrm{KHCO}_{3}, 10 \mu$ mole Na pyruvate; and 2.2 units citrate synthase $/ \mathrm{ml}$ of assay mix. Triton X-100 (octylphenoxypolyethoxyethanol) was added to solubilize the mitochondria and make the pyruvate carboxylase accessible to the assay components. Optimum activity of pyruvate carboxylase was observed when the ratio of Triton X$100(\mu \mathrm{g})$ to protein assayed $(\mu \mathrm{g})$ was between $1: 1$ and $2.5: 1$. The assay was run in small glass tubes in a total volume of $1 \mathrm{ml}$. A 3-4-min preincubation at $37^{\circ}$ in the presence of Triton X-100 and all assay ingredients except pyruvate was performed. The reaction was started by the addition of pyruvate (glass-distilled water for the blank) and run for 2 and $4 \mathrm{~min}$ at $37^{\circ}$ and stopped with $0.5 \mathrm{ml}$ $10 \%$ trichloroacetic acid. The tubes were centrifuged to remove protein, the clear supernatant was removed and bubbled with $\mathrm{CO}_{2}$ for at least $4 \mathrm{~min}$ to remove radioactive $\mathrm{CO}_{2}$, and $1 \mathrm{ml}$ the resulting fluid was added to Aqueous Counting Scintillant or Aquasol and counted in a Packard Tri-Carb scintillation spectrometer (La Grange, IL). The enzymatic activity was linear with time and amounts of tissue homogenate over the ranges used in these experiments. Tissues for assay were obtained by biopsy or within 3-4 $\mathrm{hr}$ after death, sliced thin and stored at $-78^{\circ}$ in $2.0 \mathrm{M}$ sucrose, $50 \mathrm{mM}$ potassium phosphate buffer ( $\mathrm{pH} 7.4$ ), and $5 \mathrm{mM}$ EDTA until assay. Under these conditions, Isohashi et al. (26) have found that pyruvate carboxylase activity is relatively stable for many months. For assay, a portion of the tissue was removed while still frozen, blotted, rapidly weighed and homogenized in 11 volumes of ice cold $1.5 \mathrm{M}$ sucrose, $50 \mathrm{mM}$ potassium phosphate buffer $(\mathrm{pH}$ 7.4), and 0.5 M EDTA. All kidney and liver values were corrected to allow for the dehydration of the sample (about $5 \%$ ) brought about by storage in concentrated sucrose.

PEPCK was assayed according to the method of Ballard and Hanson (4) which involves the fixation of ${ }^{14} \mathrm{CO}_{2}$ into oxalacetate in the presence of malate dehydrogenase and NADH. Citrate synthase was assayed by a spectrophotometric method (26) that depends on the release of CoA-SH in the presence of 5,5'-dithiobis (2-nitrobenzoate). The pyruvate dehydrogenase complex was as- sayed by measuring the oxidation of $\left[1-{ }^{14} \mathrm{C}\right]$ pyruvate, as described by Leiter et al. (28). Fructose-1,6-bisphosphatase (31) and pyruvate oxidation (6) were measured in leukocytes as described.

\section{MATERIALS}

Sodium $\left[1-{ }^{14} \mathrm{C}\right]$ pyruvate $(13.1 \mathrm{mCi} / \mathrm{mmole})$ and $\mathrm{NaH}^{14} \mathrm{CO}_{3}$ (>40 $\mathrm{mCi} / \mathrm{mmole}$ or $0.1 \mathrm{mCi} / \mathrm{mmole}$ ) and Aqueous Counting Scintillant were from Amersham/Searle, Arlington Heights, IL. Aquasol was obtained from New England Nuclear, Boston, MA. Other materials including phosphoenolpyruvate, inosine diphosphate, acetyl CoA, malate dehydrogenase, and citrate synthase were the highest grade materials available commercially. Thiamine triphosphate was a kind gift from Dr. J. R. Cooper, Yale University.

\section{RESULTS}

\section{CASE REPORT}

The patient, born after a normal full-term pregnancy and spontaneous delivery, had a birth weight of $3280 \mathrm{~g}$ and an Apgar score of 10. The parents are of Western European ancestry, are not related, and have two normal children. At 3 months of age, the patient was hospitalized with a fever of unknown origin and mild grand mal seizures which responded to phenobarbital. Between 5 and 9 months of age, he was readmitted three times for failure to thrive and developmental delay. A persistent mild metabolic acidosis was noted on each occasion but was not further evaluated. At 9 months of age, he developed severe metabolic acidosis and a diagnosis of lactic acidosis was made after finding a blood lactate of $6.53 \mathrm{mM}$.

Physical examination revealed a severely mentally retarded microcephalic boy who even at 46 months of age was unable to sit or feed himself and required constant nursing care. He was unable to utter recognizable words, barely responded to loud noises, and was disinterested in his surroundings. He was so retarded that it was not possible to document any loss of learned behavior. The head circumference which had been 50 th percentile at birth and 3rd percentile at 6 months was -3 SD by 2 years of age. Apart from these findings, examination including fundoscopy was normal. His weight was -1.5 SD by 2 years of age. The most notable clinical feature was the numerous sudden episodes of severe metabolic acidosis accompanied by tachypnea and a blotchy, cyanotic appearance of the extremities. These attacks, which lasted up to $1 \mathrm{hr}$, often recurred several times a day, and were not related to feeding or activity. The child died at 46 months of age as a result of pneumonia and severe acidosis.

\section{LABORATORY RESULTS}

Normal laboratory values included serum calcium, phosphorous, alkaline phosphatase, uric acid, cholesterol, thyroxine, protein electrophoresis, and plasma ammonia. Serum heavy metals, salicylates, fasting plasma insulin, free fatty acids, and chromosome analyses were normal. Examination of plasma and urine by gas liquid chromatography for organic acids revealed no abnormal metabolites other than elevated lactate and $\beta$-hydroxybutyrate. Some pertinent laboratory values are given in Table 1. Renal tubular reabsorption of amino acids was normal, creatinine clearance was $38.6 \mathrm{ml} / \mathrm{min} / \mathrm{m}^{2}$, and only when the patient was sick was there glucosuria or proteinuria, although ketonuria was often present. Skeletal x-rays were normal; there were no signs of rickets or nephrocalcinosis.

Nerve conduction and electromyography were normal. The electroencephalogram showed prominent $\theta$ waves and some abnormal slow wave activity; photic stimulation was abnormal. The test of the urine for the inhibitor associated with Leigh's disease was negative when tested by us or by J. R. Cooper, Yale University, or by J. V. Murphy, Milwaukee Children's Hospital. The urine of both parents and siblings also gave a negative test for the Leigh's inhibitor when tested by Dr. Murphy. 
Table 1. Levels of electrolytes, gases, and metabolites in the patient's blood

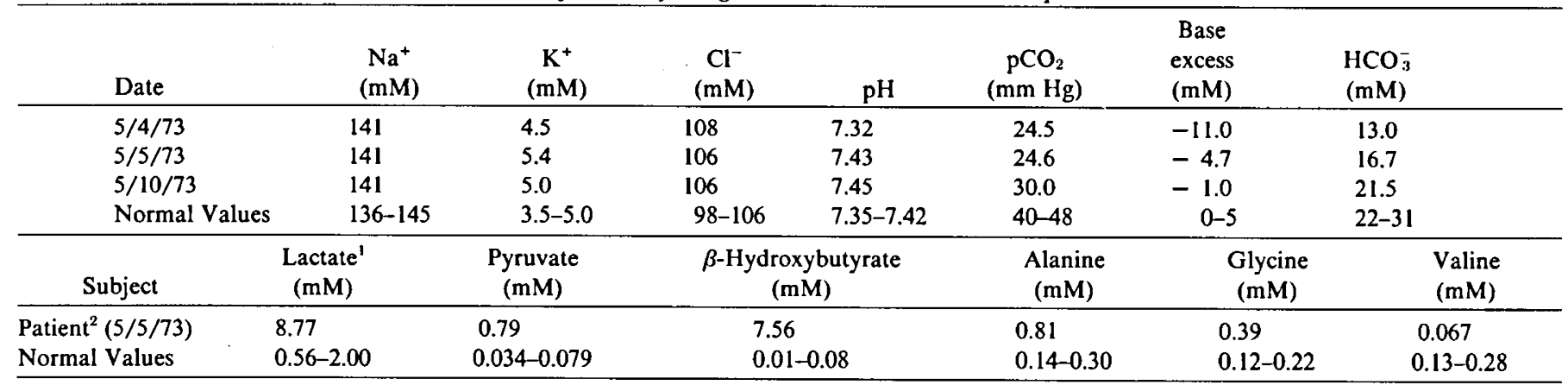

${ }^{1}$ Amino acids (8), lactate and pyruvate (25), and $\beta$-hydroxybutyrate (18) were measured as described.

${ }^{2}$ The levels are those during a severe acidotic crisis for which the patient was hospitalized. Although obtained on the same day, the blood for metabolite levels was not taken at the same time as that for blood ions and gases.

\section{SPECIAL TESTS}

The diagnosis of renal tubular acidosis was suspected because the urine $\mathrm{pH}$ was consistently greater than 7 , except during very severe acidotic episodes. The diagnosis was confirmed at 25 months of age on the basis of the data shown in Figure 2. The urine remained at $\mathrm{pH}$ 7-9 until the serum $\mathrm{HCO}_{3}^{-}$was around 10 $\mathrm{mEq} /$ liter, as occurred during the severe acidotic attacks. The diagnosis of proximal renal tubular acidosis was further substantiated by withholding $\mathrm{NaHCO}_{3}$ therapy for $12 \mathrm{hr}$ and observing the $\mathrm{pH}$ and $\mathrm{HCO}_{3}^{-}$content of the blood and urine. Evidence that the renal tubular acidosis was proximal and not distal is provided by the observation that the urine had a $\mathrm{pH}$ of 5.12 concomitant with a blood $\mathrm{pH}$ of 7.10 and a blood $\mathrm{HCO}_{3}{ }^{-}$of $1.6 \mathrm{mEq} / \mathrm{liter}$ during a spontaneous attack of acidosis unrelated to diagnostic $\mathrm{HCO}_{3}^{-}$withdrawal (Fig. 2).

The results of an oral fructose tolerance test $(2.5 \mathrm{~g} / \mathrm{kg})$ were normal, with a rise of blood glucose to $9.7 \mathrm{mM}$ at $90 \mathrm{~min}$ and a decrease to $4.7 \mathrm{mM}$ at $120 \mathrm{~min}$. There was no rise in the blood glucose following an oral alanine load $(100 \mathrm{mg} / \mathrm{kg})$ after a fast of $11 \mathrm{hr}$ (Fig. 3). After a 24-hr fast, the patient's blood glucose was $1.8 \mathrm{mM}$, the lactate $6.24 \mathrm{mM}$, pyruvate $0.49 \mathrm{mM}$ (lactate/pyruvate 12.79 ), and $\beta$-hydroxybutyrate greater than $2 \mathrm{mM}$.

\section{THERAPY}

Therapy with $\mathrm{NaHCO}_{3}$ was begun when the patient was 9 months old and continued throughout the remainder of his life. Doses of $32 \mathrm{mEq} \mathrm{NaHCO}$ every $4 \mathrm{hr}$ ameliorated his symptoms and reduced the number of acidotic attacks but did not eliminate them. Additional doses were required during acidotic attacks. During therapy with $330 \mathrm{mg}$ aspartate every $4 \mathrm{hr}$, the blood lactate and alanine were decreased and there were fewer acidotic attacks. The patient initially appeared much more alert and active but this improvement was transitory and the patient showed no developmental progress. Therapy with $50 \mathrm{mg}$ pyridoxine and $400-800 \mathrm{mg}$ L-glutamine (4l) every $4 \mathrm{hr}$ may have diminished the number of acidotic episodes. Oral biotin $(20 \mathrm{mg})$, lipoic acid $(10 \mathrm{mg})$, folic acid $(30 \mathrm{mg})$, pyridoxine $(500 \mathrm{mg})$, and im vitamin $\mathrm{B}_{12}(1 \mathrm{mg})$ were without effect.

\section{PATHOLOGIC CHANGES}

At the age of 28 months, liver and muscle (rectus abdominis) biopsies were performed for which informed consent was obtained. Microscopic examination revealed a normal hepatic lobular architecture with cellular detail consistent with that seen with the electron microscope. Electron microscopic studies of the liver revealed a hyperplasia of the smooth endoplasmic reticulum as well as a reduction of the profiles of rough endoplasmic reticulum. Numerous vacuoles contained faintly osmiophilic finely granular material which was enclosed by a single membrane. These vacuoles appeared to represent a focal dilatation of the cisternae of the

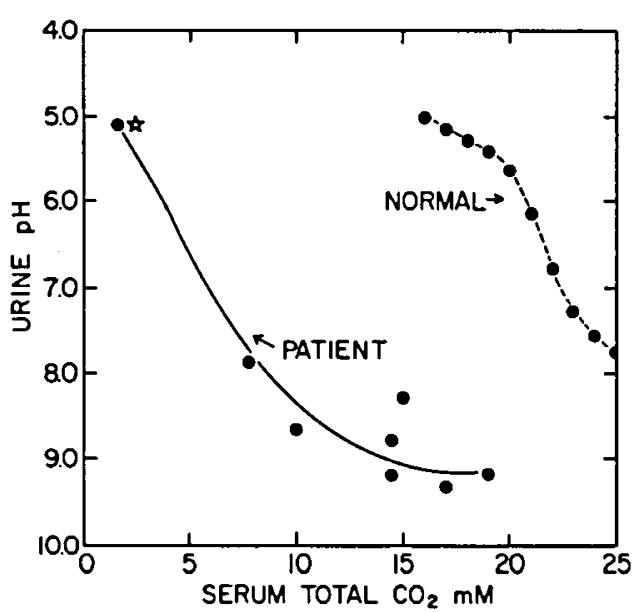

Fig. 2. Total $\mathrm{CO}_{2}$ content of serum vs. urine $\mathrm{pH}$. Values for urine are based on 24-hr collections during which the blood sample was taken. The normal curve is shown as a dashed line. At the time of the starred blood sample the patient had already received $75 \mathrm{mEq} \mathrm{HCO}_{3}{ }^{-}$to counteract a very severe acidotic attack. The blood $\mathrm{pH}$ was $7.10, \mathrm{pCO}_{2} 5.0 \mathrm{~mm} \mathrm{Hg}$, and base excess $-25 \mathrm{mM}$ at this time.

smooth endoplasmic reticulum. Glycogen granules were conspicuous in some of the cells. Many mitochondria contained paracrystalline inclusions. Lipofuchsin was frequently detected in the cytoplasm of Kupffer cells.

The muscle fibers, $10-16 \mu \mathrm{m}$ in diameter, were rounded instead of polygonal in cross-section. Ultrastructural studies disclosed an excessive number of lipid bodies in the type 1 muscle fibers.

The external configuration of the postmortem brain was normal. The lateral ventricles were mildly enlarged and the cerebral white matter, particularly the corpus collosum, was markedly reduced in amount. Microscopic examination disclosed a severe depletion of neurons in the cerebral cortex, numerous ectopic neurons in the white matter, and ectopic glia in the subarachnoid space. Myelin was poorly formed in a bilaterally symmetrical distribution in the corona radiata, internal and external sagittal strata, and the cerebellar hemisphere (Fig. 4). Such alterations in the migration of cells and the formation of myelin are characteristic of a developmental arrest of the central nervous system. In addition, there were degenerative changes represented by accumulations of macrophages in the perivascular spaces (Fig. 5) of the white matter, a subependymal gliosis (Fig. 6), and a hyperplasia of protoplasmic astrocytes in cortical structures.

Postmortem examination of the kidney revealed a diffuse vacuolation of the renal tubules, most conspicuous in the distal tubules. Fine granules were numerous with these distended tubules. In addition, within foci in the glomerular tufts, the epithelial 


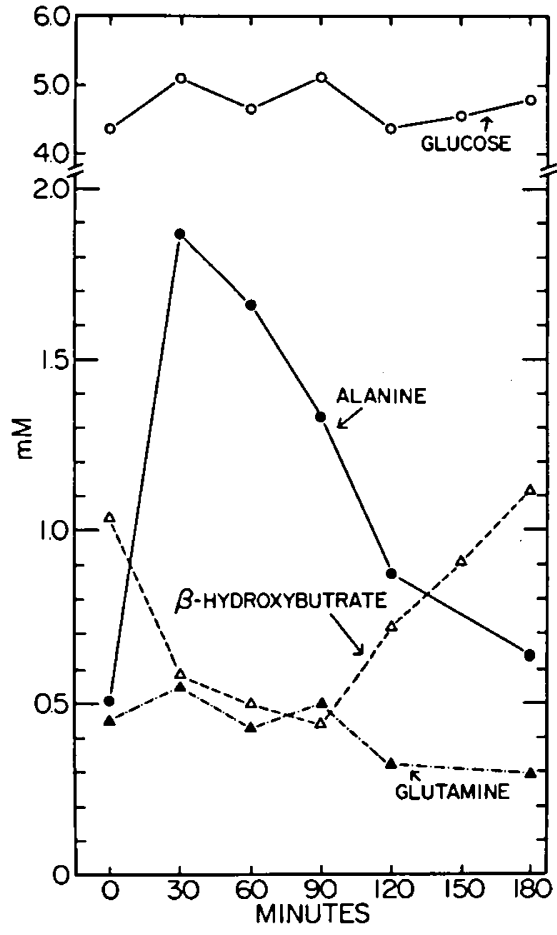

Fig. 3. Alanine load. Levels of glucose, alanine, glutamine, and $\beta$ hydroxybutyrate in the patient's blood after an oral alanine load of 100 $\mathrm{mg} / \mathrm{kg}$. and endothelial cells were increased. Thin sections of the glomerular basement membrane stained with periodic acid-Schiff revealed no thickening. In the liver, there was minimal portal fibrosis and a scanty mononuclear cell infiltrate. Glycogen was not excessive. Collections of small lipid bodies were observed in many hepatocytes. Postmortem examination disclosed multiple foci of bronchopneumonia, characterized microscopically by an inflammatory reaction, both acute and subacute, and the presence of bacteria. Bronchi were occluded by food particles, debris, and inflammatory cells.

\section{BIOCHEMICAL RESULTS}

Pyruvate carboxylase activity in the patient's liver biopsy sample was $15 \%$ of normal (Table 2), whereas the activities of the pyruvate dehydrogenase complex, PEPCK, and citrate synthase were normal. The activity of fructose-1,6-bisphosphatase in the patient's leukocytes was normal as was oxidation of $\left[1-{ }^{14} \mathrm{C}\right]$ pyruvate by the patient's leukocytes. Pyruvate carboxylase activity in the autopsy liver was about $6 \%$ of normal. As indicated in Table 2, normal values in three controls averaged about 10.5 units/g fresh weight of tissue.

Pyruvate carboxylase was also assayed in renal cortex and cerebrum (Table 3 ). In the kidney the activity was detectable but extremely low. A control value of 5.05 units/g fresh weight was obtained for the kidney from a young adult. The values for citrate synthase in the patient's kidney were normal or slightly higher than normal. As also shown in Table 3, pyruvate carboxylase activity was below the detectable level of the assay in the patient's cerebrum. The lower limit of detection is much higher in brain than in kidney, because the assay in brain is linear for a much

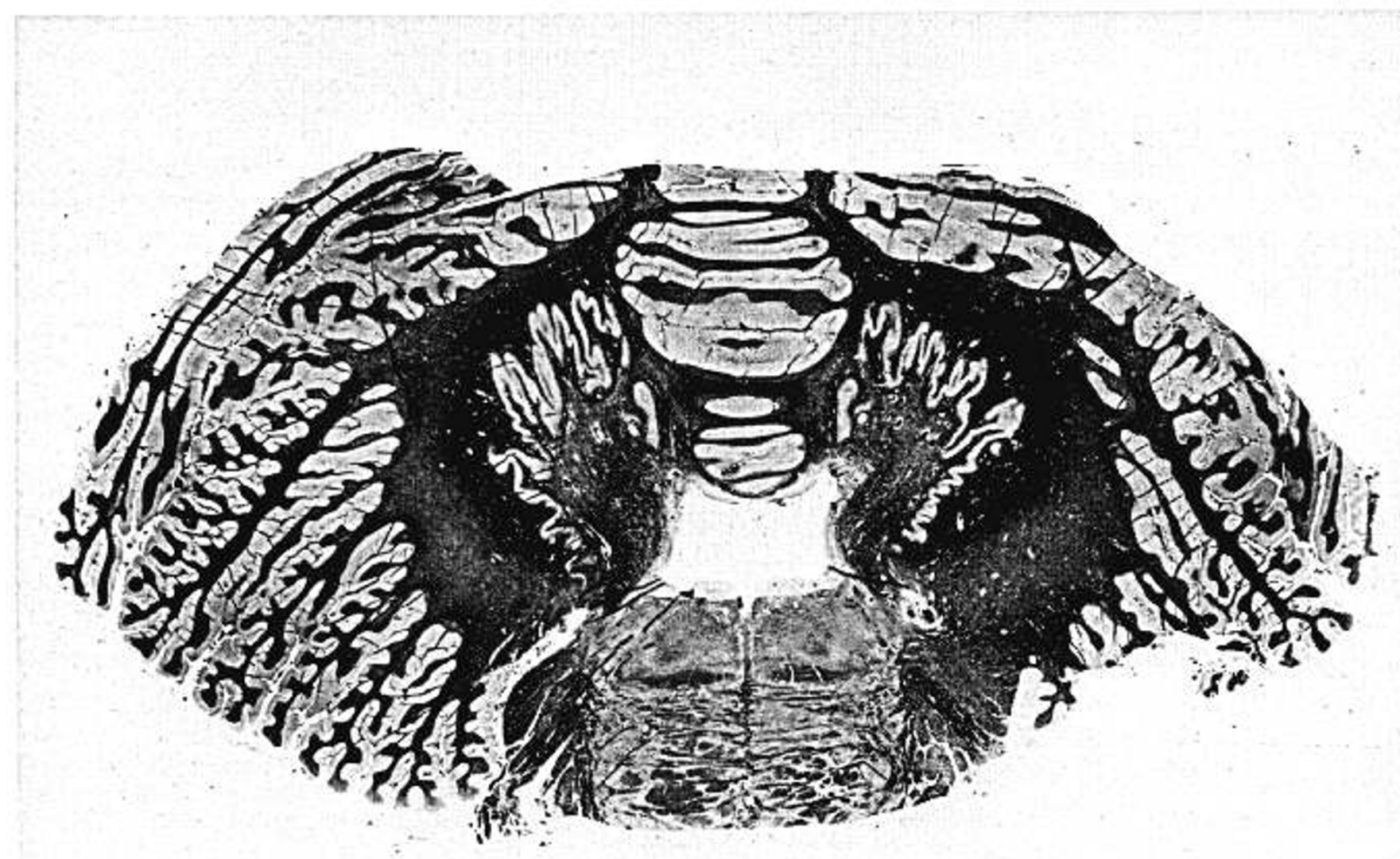

Fig. 4. Defect in myelinization. There is a failure of formation of myelin in the corpus medullare as well as in the peduncles of the cerebellum. Luxol fast blue. $\times 2$. 


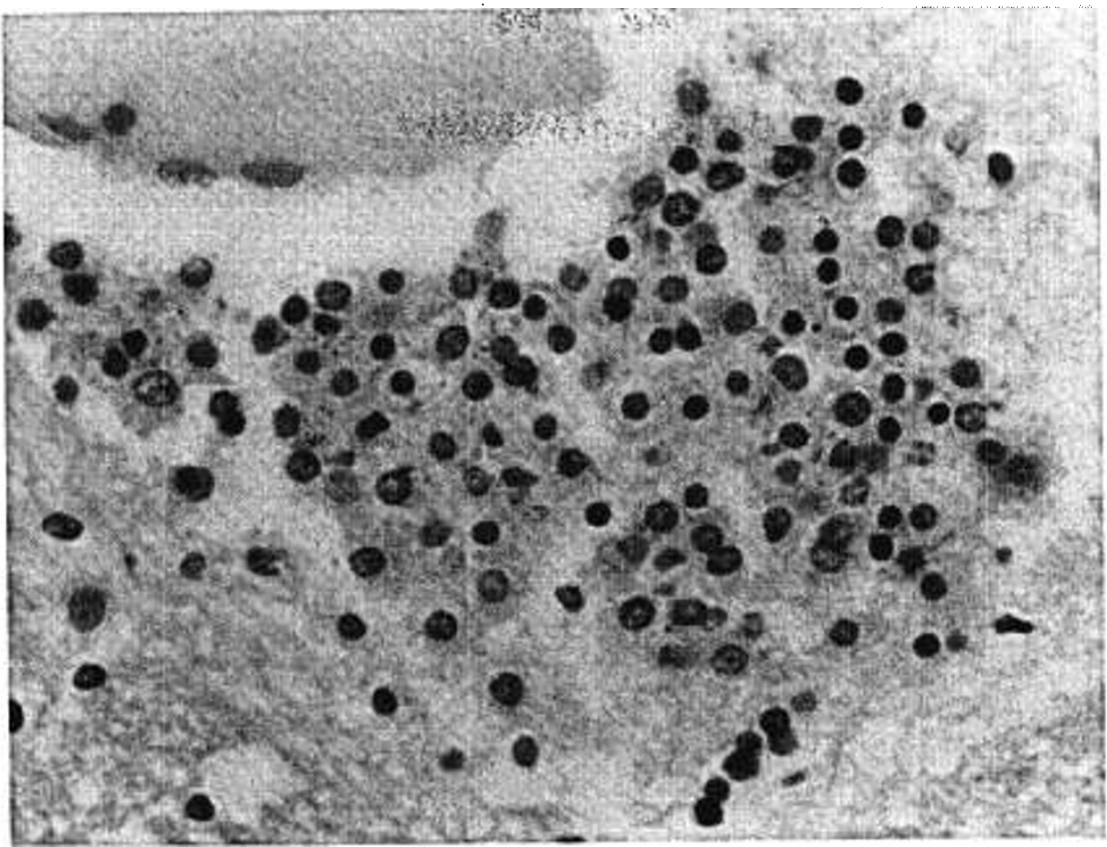

Fig. 5. Accumulation of perivascular macrophages. Collections of perivascular macrophages are abundant in the white matter of the cerebral hemispheres Hematoxylin and eosin. $\times 576$.

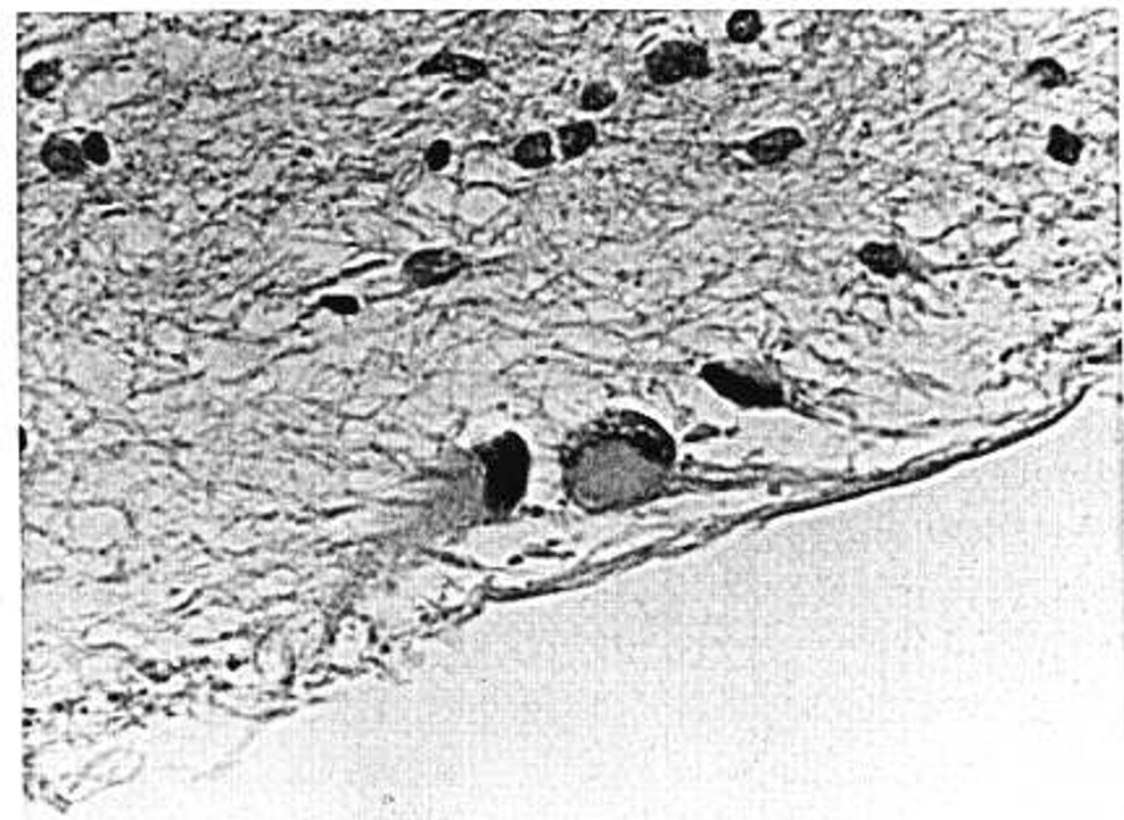

Fig. 6. Subependymal gliosis. The ventricule is denuded of ependyma in foci and in these zones a subependymal gliosis is conspicuous. Hematoxylin and eosin. $\times 592$.

shorter time than with kidney. Control values for human cerebrum were about 0.4 units/g in these studies and slightly higher for monkey brain.

Experiments in which samples of liver, kidney, and brain from the patient were mixed with similar preparations from control tissues showed no evidence in the patient's tissues of substances inhibitory to normal pyruvate carboxylase activity (Table 4) or of the presence of activators in the control tissue.

\section{DISCUSSION}

The clinical symptoms of lactic acidosis, plus elevated blood levels of $\beta$-hydroxybutyrate, alanine, and pyruvate suggested an inborn error of pyruvate or glucose metabolism. The results of the oral alanine load were consistent with a block in gluconeogenesis but were not conclusive because, even in normal individuals, the blood glucose may not increase, presumably due to the insulinogenic effect of alanine and subsequent stimulation of glucose utilization (17). A blood glucose value of $1.8 \mathrm{mM}$ after a $24-\mathrm{hr}$. fast is also consistent with a block of gluconeogenesis, but again is not conclusive because such a value may not be abnormal at this age (9). However, the abnormally high levels of lactate and pyruvate, 6.24 and $0.49 \mathrm{mM}$, respectively, observed in conjunction with the hypoglycemia after a 24 -hr fast is consistent with a block in gluconeogenesis. Furthermore, the patient exhibited the clinical symptoms of severe hypoglycemia after the test. Chronic hypoglycemia was not observed, perhaps because the residual pyruvate carboxylase activity would permit substantial gluconeogenesis from pyruvate. Furthermore, gluconeogenesis from glycerol and precursors of oxalacetate would be intact. 
Table 2. Levels of pyruvate carboxylase, citrate synthase, pyruvate dehydrogenase complex, and PEPCK in the patient's and normal liver

\begin{tabular}{lcccc}
\hline \multicolumn{1}{c}{ Tissue } & $\begin{array}{c}\text { Pyruvate carboxylase } \\
\text { (units/g fresh wt }{ }^{2} \text { ) }\end{array}$ & $\begin{array}{c}\text { Pyruvate dehydrogenase complex } \\
\text { (units/g fresh wt) }\end{array}$ & $\begin{array}{c}\text { PEPCK } \\
\text { (units/g fresh wt) }\end{array}$ & $\begin{array}{c}\text { Citrate synthase } \\
\text { (units/g fresh wt) }\end{array}$ \\
\hline Patient (biopsy) & $1.81 \pm 0.20(3)^{3}$ & $0.35 \pm 0.20(2)$ & $9.4 \pm 0.11$ & $20.8 \pm 2.45$ \\
Patient (autopsy) & $0.75 \pm 0.07(4)$ & & $4.4 \pm 0.08$ & \\
Anencephalic child (autopsy) & $10.9 \pm 0.3(9)$ & $0.21 \pm 0.015$ & & $12.3 \pm 1.4$ \\
Adult with carcinoma of pan- & 11.3 & $0.47 \pm 0.012$ & &
\end{tabular}

Adult with carcinoma of pancreas (biopsy)

Adult: death from brain hem- $\quad 9.5 \pm 1.2$ (3)

$19.8 \pm 0.45$

$10.2 \pm 0.45$ orrhage (autopsy)

Adult: death from myocardial

$12.6 \pm 0.17$

infarction (autopsy)

Adult: patient with cystic fibrosis (autopsy)

${ }^{1}$ All tissues were frozen at $-76^{\circ}$ in $2 \mathrm{M}$ sucrose, $50 \mathrm{mM}$ potassium phosphate buffer (pH 7.4), $0.5 \mathrm{mM}$ EDTA immediately (biopsies) or within 4 hr after death (autopsies) and homogenized in 11 volumes ice cold $1.5 \mathrm{M}$ sucrose, $50 \mathrm{mM}$ potassium phosphate buffer (pH 7.4 ), $0.5 \mathrm{mM}$ EDTA, and 0.1 mM dithiothreitol.

${ }^{2}$ Units represent: for pyruvate carboxylase and $\mathrm{PEPCK}, \mu \mathrm{mole} \mathrm{HCO}_{3}{ }^{-} \mathrm{fixed} / \mathrm{min}$; for pyruvate dehydrogenase complex, $\mu \mathrm{mole} \mathrm{CO}_{2}$ produced/min, for citrate, $\mu$ mole $\mathrm{CoSH}$ produced $/ \mathrm{min}$. All assays at $37^{\circ}$.

${ }^{3}$ Values are the mean \pm SE (38). Numbers in parentheses represent number of separate assays when performed.

Table 3. Levels of pyruvate carboxylase and citrate synthase in kidney and brain of the patient and controls

\begin{tabular}{|c|c|c|}
\hline Tissue' & $\begin{array}{l}\text { Pyruvate carboxylase } \\
\text { (units/g fresh } w^{2}{ }^{2} \text { ) }\end{array}$ & $\begin{array}{l}\text { Citrate synthase } \\
\text { (units/g fresh wt) }\end{array}$ \\
\hline & \multicolumn{2}{|c|}{ Kidney } \\
\hline Patient (autopsy) & $0.008 \pm 0.004(5)$ & $23.0 \pm 2.45(3)$ \\
\hline \multirow{2}{*}{$\begin{array}{l}\text { Normal } 16 \text {-year old: death } \\
\text { by auto accident }\end{array}$} & $5.05 \pm 0.24$ & $13.3 \pm 0.8$ \\
\hline & \multicolumn{2}{|c|}{ Brain } \\
\hline Patient (autopsy) & $<0.018$ & $19.8 \pm 0.30(2)$ \\
\hline $\begin{array}{l}\text { 14-year old with Down's } \\
\text { syndrome (autopsy): } \\
\text { death from congestive } \\
\text { heart failure }\end{array}$ & $0.44 \pm 0.027$ & $12.8 \pm 1.1$ \\
\hline $\begin{array}{l}\text { Normal 2-month-old the- } \\
\text { sus monkey (autopsy) }\end{array}$ & $0.53 \pm 0.015(2)$ & $20.6 \pm 0.2$ \\
\hline $\begin{array}{l}\text { Normal adult rhesus mon- } \\
\text { key (autopsy) }\end{array}$ & $0.695 \pm 0.02$ & \\
\hline
\end{tabular}

'Tissues treated as described in legend of Table 2 except brain was homogenized in nine volumes ice cold $0.22 \mathrm{M}$ mannitol, $0.070 \mathrm{M}$ sucrose, and $0.005 \mathrm{M}$ morpholinopropane-sulfonic acid, $\mathrm{pH}$ 7.4.

${ }^{2}$ Units are described in legend of Table 2. Values for kidney were corrected for dehydration. No correction was applied to values for brain.

In the renal cortex, pyruvate carboxylase is presumably involved in gluconeogenesis but the presence of proximal renal tubular acidosis in this and another patient (20) suggests that the enzyme may play an additional specific role in renal tubular function. Gruskin et al. (20) suggested that the renal tubular acidosis might arise from lack of the energy supply required for transport. This seems unlikely in the present case on the basis that other energyrequiring transport systems in the.proximal tubule appeared to be normal. It is more plausible to suggest that renal pyruvate carboxylase may play a specific role in the proximal tubular reabsorption of bicarbonate.

It is not clear in the present case whether the mental retardation and histologic abnormalities in the brain are related to the abnormal levels of metabolites in the plasma, or to the loss of cerebral pyruvate carboxylase activity. The pathologic changes in the brain are both developmental and degenerative in nature, the former having occurred during intrauterine life. These abnormalities are quite different from those which characterize Leigh's disease; in the latter, the changes take the form of bilaterally symmetric foci of necrosis and spongiform degeneration, vascular proliferation, and gliosis in the thalami, midbrain, pons, medulla, and spinal cord (1). In Leigh's disease, the changes are most prominent but not limited to the periventricular and periaqueductal zones where vascular proliferation, neuronal loss, and spongy degeneration characterize the disease process. For this reason, the alterations in Leigh's disease are necrotizing and more extensive than the gliosis which was confined to the subependymal zones in our patient. When the subcortical white matter is involved in Leigh's disease, spongy degeneration also characterizes the tissue reaction. In contrast, in our patient, the changes in cerebral and cerebellar white matter were represented by an incomplete formation of myelin and by the presence of numerous ectopic neurons. These changes appeared to represent an arrest in development of the central nervous system instead of a degeneration which characterizes the alterations in Leigh's disease (1). The changes in the white matter in our case resemble those described by Saudubray $e t$ al. (37) in an infant with congenital lactic acidosis in association with hepatic and renal pyruvate carboxylase deficiency. The developmental changes in the cortex, because of their subtlety, could easily have been overlooked in their case. A more severe affection of periventricular and hemispheric white matter has been described in two siblings with congenital lactic acidosis, mental retardation, seizures, and hypotonia (14). The enzymatic defect in the latter disorder has not been elucidated, however.

The severity of the neurologic manifestations in our case can be explained on the basis of the above neuropathologic changes. Whether or not these changes are specific for patients with pyruvate carboxylase deficiency and lactic acidosis will be determined only after more such patients are given thorough biochemical, clinical, and neuropathologic examinations.

There is a great deal of confusion concerning the possible role of pyruvate carboxylase in Leigh's disease. This is due to: 1) the assignment of a diagnosis of Leigh's disease, without autopsy confirmation, to various progressive neurologic disorders of children; and 2) the use of suboptimal storage and assay conditions for tissues to be assayed for pyruvate carboxylase activity. It is to be expected that a host of biochemical lesions might present clinically as "Leigh's disease" so broadly defined. However, if the diagnosis of Leigh's disease was confined only to those patients that have the histologic lesions described by Leigh in the brain at autopsy, correlation of a basic biochemical defect with this disease might be successful. If the more precise definition of Leigh's disease is applied to the previous reports associating Leigh's disease with pyruvate carboxylase deficiency $(10,12,19,20,22$, $40,41)$, one discovers that only the patients of Hommes and associates (12) and Gruskin and associates $(19,20)$ had autopsyproven Leigh's disease, although the patient of Tang et al. (41) did have a sibling that died of autopsy-proven Leigh's disease. 
PYRUVATE CARBOXYLASE DEFICIENCY AND LACTIC ACIDOSIS

Table 4. Lack of inhibition of normal liver, kidney, and brain pyruvate carboxylase by respective homogenates from the patient

\begin{tabular}{lcccc}
\multicolumn{1}{c}{ Tissue $^{1}$} & $\begin{array}{c}\text { Patient } \\
\text { (units/g fresh wt }{ }^{2} \text { ) }\end{array}$ & $\begin{array}{c}\text { Normal } \\
\text { (units/g fresh wt) }\end{array}$ & $\begin{array}{c}\text { Mixture }^{3} \\
\text { (units/g fresh wt) }\end{array}$ & $\begin{array}{c}\text { Expected } \\
\text { (units/g fresh wt) }\end{array}$ \\
\hline $\begin{array}{l}\text { Liver } \\
\text { (autopsy) }\end{array}$ & $0.73 \pm 0.01$ & $11.0 \pm 0.3$ & $5.9 \pm 0.4$ & 5.9 \\
$\begin{array}{l}\text { Kidney } \\
\text { (autopsy) }\end{array}$ & $0.003 \pm 0.0006$ & $5.3 \pm 0.7$ & $2.4 \pm 0.66$ & 2.6 \\
$\begin{array}{l}\text { Brain } \\
\text { (autopsy) }\end{array}$ & $<0.018$ & $0.44 \pm 0.005$ & $0.21 \pm 0.01$ & 0.22 \\
\hline
\end{tabular}

' All tissues treated as described in legends of Tables 2 and 3.

${ }^{2}$ Units are as described in the legend of Table 2. ${ }^{3}$ The mixtures were composed of equal volumes of patient and normal homogenates. Liver was incubated on ice for $12 \mathrm{~min}$, kidney for $17 \mathrm{~min}$, and
brain for $54 \mathrm{~min}$ before assay.

However, the patient of Gruskin et al. had normal hepatic pyruvate carboxylase activity at biopsy, and the authors themselves (20) speculated that the absence of pyruvate carboxylase at autopsy was a secondary phenomenon. The patient of Hommes et al. (22) had decreased pyruvate carboxylase activity upon biopsy by needle, but this result must be interpreted with caution because the tissue was homogenized in hypotonic buffer, $10 \mathrm{mM}$ Trishydroxymethylaminomethane, $\mathrm{pH} 7.55$, without the protective action of either sucrose or mannitol. Thus, although these patients had autopsy-proven Leigh's disease, the demonstration of pyruvate carboxylase deficiency is not unequivocal.

In contrast, there are the patients in whom pyruvate carboxylase deficiency was demonstrated but Leigh's disease was found to be absent at autopsy; represented by the case reported here and possibly that of Saudubray et al. (37). The patient of DeVivo et al. (13) probably also belongs in this category, although unfortunately this can not be confirmed because the brain was no available for autopsy study. In conclusion, the lack of any patient with unequivocal pyruvate carboxylase deficiency concomitant with autopsyproven Leigh's disease, and the demonstration that the present patient had cerebral and hepatic pyruvate carboxylase deficiency without Leigh's disease suggests that the previous association of Leigh's disease and pyruvate carboxylase deficiency may not have been justified. The patient presented here is the first case of hepatic and cerebral pyruvate carboxylase deficiency in whom the developmental and degenerative lesions were documented by a thorough neuropathologic examination and shown to be different from those of Leigh's disease. This case provides the strongest evidence to date that the neuropathologic lesions in pyruvate carboxylase deficiency may be quite distinct from those of patients diagnosed, at autopsy, to have had Leigh's disease.

\section{REFERENCES AND NOTES}

1. Adams, R. D., and Victor, M.: Principles of Neurology, (McGraw Hill, NY, 1977).

2. Ando, T., Rasmussen, K., Nyhan, W. L., Donnell, G. N., and Barnes, N. D.: Propionic acidemia in patients with ketotic hyperglycinemia. J. Pediatr., 78: 827 (1971).

3. Atkin, B. M., Utter, M. F., and Weinberg, M. B.: Pyruvate carboxylase and phosphoenolpyruvate carboxykinase activity in leukocytes and fibroblasts from a patient with pyruvate carboxylase deficiency. Pediatr. Res. 3: 38 (1979).

4. Ballard, F. J., and Hanson, R. W.: Phosphoenolpyruvate carboxykinase and pyruvate carboxylase in developing rat liver. Biochem. J., 104: 866 (1967).

5. Ballard, F. J., Hanson, R. W., and Reshef, L.: Immunochemical studies with soluble and mitochondrial pyruvate carboxylase activities from rat tissues. Biochem. J., 119: 735 (1970).

6. Blass, J. P., Avigan, J., and Uhlendorf, B. W.: A defect in pyruvate decarboxylase in a child with an intermittent movement disorder. J. Clin. Invest., 49: 423 (1970).

7. Brunette, M. G., Delvin, E., Hazel, B., and Scriver, C. R.: Thiamin-responsive lactic acidosis in a patient with deficient low- $K_{m}$ pyruvate carboxylase activity in liver. Pediatrics, 50: 702 (1972)

8. Buist, N. R. M., and Strandholm, J. J.: Experience with combined amino acidpeptide analysis of physiological fluids. In: Technicon International Symposium, Vol. 1, p. 321 (Mediad. Inc., NY, 1970).

9. Chaussain, J. L.: Glycemic response to 24 hour fast in normal children and children with ketotic hypoglycemia. J. Pediatr., 82: 438 (1973).

10. Cooper, J. R., and Pincus, J. H.: Thiamin triphosphate deficiency in Leigh's disease (subacute necrotizing encephalomyelopathy). In: F. A. Hommes and C. J. Van den Berg: Inborn Errors of Metabolism, p. 119 (Academic Press,
Inc., London, 1973).

11. Cooper, J. R., Pincus, J. H., Itokawa, Y., and Piros, K.: Experience with phosphoryl transferase inhibitor in subacute necrotizing encephalomyelopathy. N. Engl. J. Med., 283: 793 (1970).

12. DeGroot, C. J.. Jonxis, J. H. P., and Hommes, F. A.: Further studies on Leigh's encephalomyelopathy. In: J. Stern and C. Toothill: Society for the Study of Inborn Errors of Metabolism, Organic Acidurias, p. 40 (Livingstone Press, Edinburgh, 1972).

13. DeVivo, D. C., Haymond, M. W., Leckie, M. P., Bussmann, Y. L., McDougal, Jr., D. B., and Pagliara, A. S.: The clinical and biochemical implications of pyruvate carboxylase deficiency. J. Clin. Endocrinol. Metabl, 45: 1281 (1977).

14. Farkas-Barteton, E., Goutieres, F., Richardet, J. M., Thieffry, S., and Brissaud. H. E.: Leucoencephalopathie familiale associee a une acidose lactique congenitale. Acta Neuropathol., 17: 156 (1971).

15. Farrell, D. F., Clark, A. F., Scott, C. R., and Wennberg, R. P.: Absence of pyruvate decarboxylase activity in man: A cause of congenital lactic acidosis. Science, 187: 1082 (1975).

16. Fiser, Jr., R. H., Melsher, H. L., and Fisher, D. A.: Hepatic phosphoenolpyruvate carboxykinase (PEPCK) deficiency. A new cause of hypoglycemia in childhood. Pediatr. Res., 8: 432 (1974).

17. Genuth, S. M., and Castro, J.: Effect of oral alanine on blood $\beta$-hydroxybutyrate and plasma glucose, insulin, free fatty acids, and growth hormone in normal and diabetic subjects. Metab. Clin. Exp., 23: 375 (1974).

18. Gibbard, S., and Watkins, P. J.: A micro-method for the enzymatic determination of $\mathrm{D}-\beta$-hydroxybutyrate and acetoacetate. J. Clin. Acta, 19: 511 (1968)

19. Grover, W. D., Auerbach, V. H., and Patel, M. S.: Biochemical studies and therapy in subacute necrotizing encephalomyelopathy (Leigh's syndrome). J. Pediatr., 81: 39 (1972).

20. Gruskin, A. B., Patel, M. S., Linshaw, M., Ettenger, R., Huff, D., and Grover, W.: Renal function studies and kidney pyruvate carboxylase in subacute necrotizing encephalomyelopathy (Leigh's syndrome). Pediatr. Res., 7: 832 (1973).

21. Hommes, F. A., Bendien, K., Elema, J. D., Bremer, H. J., and Lombeck, I.: Two cases of phosphoenolpyruvate carboxykinase deficiency. Acta Paediatr. Scand., 65: 233 (1976).

22. Hommes, F. A., Polman, H. A., and Reerink, J. D.: Leigh's encephalomyelopathy: An inborn error of gluconeogenesis. Arch. Dis. Child., 43: 423 (1968).

23. Horning, M. G.: Gas phase analytical methods for the study of urinary acids. In: H. A. Szymanski: Biomedical Applications of Gas Chromatography, p. 53 (Plenum Press, NY, 1968)

24. Howell, R. R., Ashton, D. M., and Wyngaarden, J. B.: Glucose 6-phosphatase deficiency glycogen storage disease. Studies on the interrelationships of carbohydrate, lipid, and purine abnormalities. Pediatrics, 29: 553 (1962).

25. Huckabee, W. E.: Control of concentration gradients of pyruvate and lactate across cell membranes in blood. J. Appl. Physiol., 9: 163 (1956).

26. Isohashi, F., Leiter, A., Weinberg, M., Utter, M. F., and Murphy, J.: Unpublished observations.

27. Leigh, D.: Subacute necrotizing encephalomyelopathy in an infant. J. Neurol. Neurosurg. Psychiatry, 14: 216 (1951).

28. Leiter, A. B., Weinberg, M., Isohashi, F., Utter, M. F., and Linn, T.: Relationship between phosphorylation and activity of pyruvate dehydrogenase in rat liver mitochrondria and the absence of such a relationship for pyruvate carboxylase. J. Biol. Chem., 253: 2716 (1978).

29. Lowe, C. U., Sokal, J. E., Mosovich, L. L., Sarcione, E. J., and Doray, B. H.: Studies in liver glycogen disease. Effects of glucagon and other agents on metabolic pattern and clinical status. Am. J. Med., 33: 4 (1962).

30. Lowry, O. H., Rosebrough, N. J., Farr, A. L., and Randall, R. J.: Protein measurements with the Folin phenol reagent. J. Biol. Chem., 193: 265 (1951).

31. Melancon, S. B., Khachadurian. A. K., Nadler, H. L., and Brown, B. I.: Metabolic and biochemical studies in fructose 1,6-diphosphatase deficiency. J. Pediatr., 82: 650 (1973).

32. Pagliara, A. S., Karl, I. E., Keating, J. P., Brown, B. I., and Kipnis, D. M.: Hepatic fructose 1,6-diphosphatase deficiency. J. Clin. Invest., 51:2115 (1972).

33. Perry, T. L., Hansen, S., Diamond, S., Bullis, B., Mok, C., and Melancon, S. B.: Volatile fatty acids in normal human physiological fluids. Clin. Chim. Acta,
29: 369 (1970).

34. Pincus, J. H.: Subacute necrotizing encephalomyelopathy (Leigh's disease): a consideration of clinical features and etiology. Child Neurol., 14: 87 (1972).

35. Pincus, J. H., Cooper, J. R., Piros, K., and Turner, V.: Specificity of the urine 
inhibitor test for Leigh's disease. Neurology, 24: 885 (1974).

36. Robinson, B. H., and Sherwood, W. G.: Pyruvate dehydrogenase phosphatase deficiency: A cause of congenital chronic lactic acidosis in infancy. Pediatr. Res., 9: 935 (1975).

37. Saudubray, J. M., Marsac, C., Charpentier, C., Cathelineau, L., Besson Leaud, M., and Leroux, J. P.: Neonatal congenital lactic acidosis with pyruvate carboxylase deficiency in two siblings, Acta Paediatr. Scand., 65: 717 (1976).

38. Snedecor, G. W., and Cochran, W. G.: Statistical Methods, sixth edition (Iowa State University Press, Ames, 1967).

39. Stromme, J. H., Borud, O., and Moe, P. J.: Fatal lactic acidosis in a new born attributable to a congenital defect on pyruvate dehydrogenase. Pediatr. Res., 10: 60 (1976).

40. Tada, K., Sugita, K., Fujitani, K., Uesakai, T., Takada, G., and Omura, K. Hyperalanininemia with pyruvicemia in a patient suggestive of Leigh's encephalomyelopathy. Tohoku J. Exp. Med., 109: 13 (1953).

41. Tang, T. T., Good, T. A., Dyken, P. R., Johnsen, S. D., McCreadie, S. R., Sy, S.

Copyright $\odot 1979$ International Pediatric Research Foundation, Inc. 0031-3998/79/1302-0109\$02.00/0
T., Lardy, H. A., and Rudolph, F. B.: Pathogenesis of Leigh's encephalomyelopathy. J. Pediatr., 81: 189 (1972).

42. Utter, M. F., and Keech, D. B.: Pyruvate carboxylase. I. Nature of the reaction. J. Biol. Chem., 238: 2603 (1963).

43. The authors would like to thank Robert D. Koler, M.D. for his encouragement and helpful criticism. The assistance of Banoo M. Jhaveri, M.D. and David D. Weaver, M.D. is gratefully acknowledged. The authors wish to thank Cecilia Hepburn and Helen Curtis for their expert technical assistance and the staff of the Providence Child Center.

44. Part of this work appeared in an abstract of the 27th Annual Meeting of the American Society Human Genetics, [Am. J. Hum. Genet., 27: 14A (1975)]. Part of this work was supported by NIH Grants HD-00165 and AM-12245 and by grants from the National Foundation-March of Dimes C-195 and a National Foundation-March of Dimes Starter Grant to M. F. Utter.

45. Received for publication December $2,1977$.

46. Accepted for publication March 29, 1978. 